\title{
Infinite Vision of Arthur Miller
}

Munna Lal

Research Scholar

M.J.P. Rohilkhand University

Bareilly, Utter Pradesh, India

mtalib282@gmail.com

Dr. S.K. Agrawal

Supervisor

Vardhaman (P.G.) College

Bijnor, Utter Pradesh, India

\section{Abstract}

Apart from social, economic and political questions, Arthur Miller was equally interested in ethical and spiritual issues. He tried to answer many questions regarding the origin of man and woman upon this planet. Of course, he had great faith in the working of divine system and the presence of God. Like Robert Browning and R.W. Emerson, he believed in merciful God and regarded Him the creator and preserver of human life and natural objects. Like Hindu saints, he asked himself — Who am I? What is the aim of life? What is the significance of self-illumination? Why are people misguided by ego, pride, lechery, greed, violence, folly, vanity etc. and ultimately suffer. But due to his optimism he believed that life can be made better if efforts are made by all kinds of people. His infinite vision is elaborated and analyzed in this article as he shows his faith 
in mercy, wisdom, right action, right knowledge and right conduct. There is no denying the fact that in his tragedies he shows no indifference to ethical values and answers the questions — 'How to live?'

Keywords: INFINITE, VISION Pride, Economic, Vanity

Introduction:

Arthur Miller felt interested in various questions regarding purity of mind, soul, eternal soul, The Bible, sin, punishment of heretics and other mysterious things. There was feeling of terror in the eyes of people living in Salem and nearby place (1642) as they failed to understand God, over-soul and divine justice. And Miller penetrated into the depth of reality that escaped the eyes of many social critics. Like William Godwin and P.B. Shelley, he was a realist who wanted to establish the victory of wisdom and justice. To him, only pure religious feelings can give solace to a man in times of moral crisis. Regarding the prevailing guilt in society he remarked in the Introduction to Collected Plays :

In The Crucible, however, there was an attempt to move beyond the discovery and unveiling of the hero's guilt, a guilt that kills the personality. I had grown increasingly conscious of this theme in my past work ... Now guilt appeared to me no longer the bedrock beneath which the probe could not penetrate. I saw it now as a betrayer, as possible the most real of our illusions, but nevertheless a quality of mind capable of being overthrown. (ICP 41) 
He asked people not to take religion as an illusion as the mercy of Almighty God can be felt and received without any problem. Of course, they have to realize the cunningness of cunning authorities of church. The Bible is a sacred book in itself and there is nothing wrong with Ten Commandments. One can lead a decent life if one follows them in daily life. To him, religion guides people to lead ethical life so that they may feel connected with God. Of course, they have to be conscious of their duties towards society as a whole. They must get rid of violence, greed, lechery, possessiveness, wickedness, desolation, ego, sense of pride, gluttony etc. so that there is no sense of fear in them. They have to cultivate moral values such as generosity, mercy, self-restraint, self-control, selfanalysis, self-resolution, righteousness etc. so that they may not go astray. They have to listen to the voice of their conscience and face the problems of life. Like saints, Miller accepted that good and evil have always existed in society and people have to avoid the temptations for material gains that lead a person to his fall. The character has got to be maintained with self-restraint. He presented the conflict between God and Lucifer in The Creation of The World And Other Business and described the problems of God that He faces in controlling human affairs. Regarding the role of passions in life he remarked in The Introduction to Collected Plays :

I think that my course in The Crucible should have been toward greater self-awareness and not, as my critics have implied, towards an enlarged and more pervasive subjectivism. The realistic form and style of the play would then have had to give way. What new form might have evolved I cannot now say, but certainly the passion of knowing is as powerful as the passion of feeling alone, and the 
writing of the play broached the question of that new form for me. (ICP 45)

After studying the books on human psychology and novels of James Joyce, Henry James, Dorothy Richardson, Virginia Woolf etc. he accepted the role of passions in human life. He was shocked to find chaos in the mind and heart of human beings. Like Shakespeare's Hamlet, he found the conflict between two forces in mind. In Introduction to Collected Plays :

For myself, it has never been possible to generate the energy to write and complete a play if I know in advance everything it signifies; and all it will contain. The very impulse to write, I think, springs from an inner chaos crying for order, for meaning, and that meaning must be discovered in the process of writing or the work lies dead as it is finished. (ICP 37-38)

Due to his strong faith in positive psychology he suggested ways and means to control dark thoughts so that people may lead a life of hope and enlightenment. Nobody can deny that he asked the audience to remain optimistic in life as gloomy hours will also pass away with the passage of time. Towards the end of tragedy All My Sons Joe Keller fails to tolerate his sense of guilt and commits suicide. On his death Kate tells Chris — 'Live'. It means that death is nothing and life is everything. To him death does not provide solution of any problem. After all human beings have to struggle hard in life inspite of all oddities and strains. Why to be sad, dull and morose? If one weeps during days of misery, he weeps alone. After all life is worth living and the heroes of Arthur Miller struggle hard for a life of dignity. 
In The Creation Of The Earth And Other Business, After The Fall, The Crucible etc. Miller asserts the value of noble thoughts and positive psychology. To him noble thoughts are the best medicine to cure many physical diseases. Grand thoughts take origin in the mind of noble people and influence their daily actions. Nobody can deny that noble thoughts decide the future life of people. People get bliss in life when they practise sublime thoughts in their conduct. A person can feel real bliss of life when he has faith in positive psychology and condemns negative approach to life. Every person must try to imitate the life of noble citizens of society so that his own life may also be superb. Best thoughts provide regular mental strength to the doers. It is with lofty thoughts that a person gathers strength to face negative thoughts. For this it is essential to join the company of noble saints and study the scriptures. Unless people listen lectures on positive thoughts they can't make life pure. Quite often people feel attracted towards grand buildings, costly garments, golden ornaments and high standard of living. Such people generally go astray and are stuck in the world of Maya. But a noble person can get rid of this illusion with positive psychology. If he is used to a life of physical comforts, he has to struggle to come out of his comfort zone so that he may make real progress in life. In All My Sons Chris makes all possible efforts to neglect the comforts that Joe Keller has managed with foul money. He hates his father as he comes to know the realities behind Joe's success.

Arthur Miller accepted that negative forces may succeed for a short time. Yet mind has got to be improved with positive forces in general interest of mankind. Hatred, envy, jealousy, violence, lawlessness, greed, lechery etc. are negative forces and Lucifer is their Lord. Only a small negative force may harm a 
man of character and create unhealthy atmosphere in society. In The Crucible the lechery of Abigail is responsible for the miseries of John Proctor and Elizabeth is well aware of it. Quite often the influence of negative forces is seen by observers of society like Miller. In Dr. Faustus the great German scholar loses his path of virtue due to his lust for knowledge of necromancy. As he wants to enjoy physical pleasures for twenty-four years, he loses his soul to Lucifer and is ultimately doomed. It is too late when he repents for his foul deeds.

\section{Exposition:}

In The Crucible Arthur Miller asserts that people become dull, sad and dormant during miserable days and lose their spiritual strength. But men of positive psychology know how to struggle during days of adversity. They face all the problems of their way as ups and downs appear in everybody's life. Life is after all not a bed of roses. John Proctor and Elizabeth try to compose themselves after the former is arrested for adultery. Due to his sense of self-dignity he does not want to lead the life of a sinner. Hathorne and Danforth grant him the opportunity to get pardoned by law. But his sense of honour does not allow him to compromise with evil. He tries his best to conquer his sense of fear as he has compromised with his creator. His positive approach becomes the torch-bearer of his life and he triumphs with his death. He has a feeling of new awakening on the verge of death and Elizabeth knows it well. He gets rid of his physical pain, mental anguish and agony as he is truthful before God, the preserver of positive values. A hidden joy lurks in his eyes even towards the end of life as this death is only physical and his soul is going to be liberated from worldly bondage. In place of physical comforts he thinks of the bright rays of divinity and hence a symbol 
of spiritual growth. Here Miller proves that the freedom from earthly worries is possible only with positive psychology. All the above mentioned characteristics of positive and negative psychology have been explained by Steve Boumgardner and Marie Crothers in their book Positive Psychology.

The problem of blasphemy has been wisely related with partial justice of U.S. Town in this tragedy. A country is great where people get fair trail. But darkness spreads in society when virtuous people like John Proctor become the victims of whims of judges like Reverent Parris, Danforth, Hathorne etc.

Like Dante, Christopher Marlowe, John Milton etc. Miller took interest in the problems created by Lucifer and his companions. In a brief note to The Crucible he admits that he studied many records of cases of witchcraft and monster's fire. Real incidents took place in many U.S. towns upto $17^{\text {th }}$ century and Salem was no exception. While writing this tragedy he mixed history with imagination though due importance has been added to probability. He has taken a few characters from history and yet clothed them in new form. A few dates have been changed to create the effect of probability and realism. All the historical events and characters appear reliable and readers accept them. He has made several remarks against witchcraft, blasphemy and heresy as he was highly rational. Hathorne and Danforth are symbols of partial justice. A few characters have been created by him with his own imagination.

With his tragedies Arthur Miller has depicted the fact that common people are usually crushed by various social, economic and political forces. Quite often they suffer due to their illusions regarding fate, God and supernatural forces. Every tragedy of Miller is remarkable for high seriousness, as being the follower of Aristotle, he never attempted to write a comedy full of wit, humour and satire. 
In his leisure hours he felt inner agony due to prevailing chaos and anarchy in every field of life and yet hoped for the possibility of social reconstruction and economic regeneration. For him, man is always important as he is the centre of all human relationships. He accepts that man can't avoid his social and political responsibilities for a long time. His tragedies confirm that his heroes don't surrender before adverse circumstances as they are highly conscious of selfdignity. In the essay Tragedy And The Common Man he confirms that human beings must struggle hard to gain their rightful place in society - Why to tolerate the mental world of indignity? For this he presents neither saints nor sinners. Due to hamartia every hero is responsible for his doom. The heroes of Miller analyze their thoughts, situations and the hostile forces. Of course, Miller presents the conflict between positive and negative forces. People like John Proctor and Elizabeth feel stifled due to hostile forces and find themselves helpless. His heroes don't migrate to any supernatural world for their struggle as earth is the right place for them. Till his death Miller didn't lose his hope for better world.

While analyzing the value of ethical values many questions came to Miller's mind such as - What is the source of conflict between positive and negative forces? Is church really required by people? Are bishops and priests totally corrupt? Are the judges in a hurry every time and don't pay attention to the merits of a legal case? Are they indifferent to moral questions? Is family life ruined due to growth of materialism? Is home no more a place for rest and peace? Are modern women not ready to adjust in the family? Is it no more possible to maintain social order? Are ethical values totally chilled after the two world wars? Is there no hope for the revival of hope, vigour, zeal, action, fortitude, toler ance, 
courage etc. in society? So he exposed the contemporary evils to analyze them minutely and also get the reaction of his audience about various evils. He admitted that a wide gap existed between personal desires and social responsibility. With his tragedies he tried to awaken this sense of social responsibility as his hopes were alive. In each tragedy Miller asserted the basic fact that each individual must perform his social duty as society can't run with greed, lechery, ego, violence, pride, corrupt ways, selfishness and other vices. Like the Greek philosophers, he accepted the theory of poetic justice. Affection and love ultimately triumph against guilt, doubts, delusion, accusation etc.

Nucleus:

Miller used to refer to his concept of mankind as expressed in The Crucible and interviews and this play was very much admired by the audience. Here the basic conflict is between pure religion and witchcraft. Then there is conflict between John Proctor and Abigail. The conflict between John Proctor and the judges can't be ignored. The existing church came in conflict between the tradition and modernity. Well, Miller failed to tolerate the tyranny of rigidity, orthodoxy, conservative, tradition etc. as he was a supporter of change and modernity. With John Proctor he rebels against conservative judges like Danforth, Reverend Parris and Hale. How could the judges ignore the innocence of John Proctor? Was John Proctor a prostitute of mind and soul? Was Abigail not an impure woman, a symbol of lust and lechery? The readers/audience are made to realize that The Crucible is not just a record of historical events of $17^{\text {th }}$ century. It is a document on moral ethics. Many questions regarding personal freedom, sexual passions, religious freedom, individual repression, wild civilization, 
corrupt judges, degrading economic values, puritan ethics etc. have been frankly analyzed here. The artist paints the people who rebel against established church and their sufferings. The artist accepts the authority of each individual in matters of personal faith and condemns the distortion of ethical issues. Thomas P. Adler aptly remarks :

Those who felt the least rebellion against the establishment were almost forced, then, to channel their own guilt into accusations demonizing the other. Several commentators have suggested that when Miller comes to set up the conflict between Puritan theocracy and the authority of individual conscience in The Crucible he might be distorting aspects of the former in order unswervingly to expose the latter. (CCAM 92)

As a matter of fact John Proctor becomes the victim of the arrogance of his judges. They have no ethical values to support their judgment. The author observed that one generation does not necessarily impart ethics to the next generation. However, traditions and rituals are generally followed for generations. Very important questions have been raised in this tragedy such as Did witches exist in the world? What were their shapes? Where did they come for? Are they instruments of justice? What were they made of? Were they messengers of Lucifer real? Well, as an iconoclast Miller turned down all these questions as he had no faith in witchcraft. He boldly said :

I saw forming a kind of interior mechanism of confession and forgiveness of sins which until now had not been rightly categorized as sins. New sins were being created monthly. It was very odd how 
quickly these were accepted into the new orthodoxy, quite as though they had been there since the beginning of time. Above all, above all horrors, I saw accepted the notion that conscience was no longer a private matter but one of state administration. I saw men handing conscience to other men and thanking other men for the opportunity of doing so. (IPC 41)

He had so many questions to ask from the prosecutors of John Proctor such as - How did they reach the conclusion that John Proctor was a sinner? How did he disturb moral order of society? Couldn't he be pardoned and given the benefit for doubt? Was his wife not pure at heart? Was she not faithful to him? Well, the various aspects of evil have not been analyzed wisely by them as if they had decided the decision before listening the arguments of accused people. Miller felt shocked when Rebecca Nurse was badly treated in the court and nobody bothered for her chaste life. Miller said :

I recall, almost as in a dream, how Rebecca Nurse, a pious and universally respected woman of great age, was literally taken by force from her sickbed and ferociously cross-examined. No human weakness could be displayed without the prosecution's stabbing into it with greater fury. The most patent contradictions, almost laughable even in that day, were overridden with warnings not to repeat their mention. There was a sadism here that was breathtaking. (ICP 43)

Like judge Pilate, the justice in the case of Christ, Danforth, Hale and other judges didn't realize the truth of the matter and innocent John Proctor had 
to suffer for their negligence. He had to suffer due to the lecherous conduct of Abigail and Elizabeth is fully conscious of this. Miller argued :

The society of Salem was 'morally' vocal. People then avowed principles, sought to live by them and die by them. Issues of faith, conduct, society, pervaded their private lives in a conscious way. They needed but to disapprove to act. I was drawn to this subject because the historic moment seemed to give me the poetic right to create people of higher self-awareness than the contemporary scene affords. (ICP 44)

As a matter of fact, John Proctor has no personal ego. He just wants to lead a normal family life with his wife. He is fully conscious of the past evil deed that he has committed. Due to his positive approach to life he confesses his guilt before the judges and wishes to be pardoned for the same. But alas! His hope remains unfulfilled as he is punished for adultery. His hope proves to be a heavy burden though the judges are eager to forgive him. His prayer for relief is real and yet he remains impractical. His desires are not unlimited as he aspires for no material gains. However, he suffers because he is unaware of the hard realities of life. But he had no interest in blasphemy and heresy. The church authorities had no right to punish him as he possesses a noble heart. The question arises - Why does he suffer ultimately? The only answer to this question is that he lacks practical wisdom. He fails to compromise with the loss of personal dignity.

Conclusion: 
In the essay Circles Ralph Waldo Emerson asserts that there are circles for everybody in which he/she has to move so that discipline may be maintained in society. After all ethical values can't be neglected as people can't survive in the state of anarchy, chaos and lawlessness. Unfortunately greedy and ambitious people break the ethical circles as they wish to achieve their goals at every cost. In this process they cause loss to society and often invite various problems for themselves also. I fail to understand as to why many leaders of society are not prepared to live within their allotted circles. Why do they not accept the realities of life which are intimately connected with universal circles? How can they tolerate the downfall of society merely for the fulfilment of their ambitions? As a matter of fact it becomes their tendency to break the social, political, economic and cultural circles. Their dreams, expectations and sense of competition with others are responsible for prevailing indiscipline in society.

Arthur Miller had studied this essay and Ibsen's tragedy An Enemy Of The People. He reinterpreted Ibsen's tragedy in his own way and took the title from Ibsen. In All My Sons he had depicted Joe Keller as the enemy of soldiers who used the defective cylinders as supplied by Joe's factory due to greed. In The Crucible he exposed the judges who failed to give justice to John Proctor. Corrupt Abigail tries her level best to protect her reputation though she is not pure at heart. In A View From The Bridge Eddie pretends to be virtuous though he is lustful. Rodolpho pretends to be a pure lover of Catherine though he wants to marry her just for getting the green card in America. So many people of Arthur Miller want to improve their lot in prosperous U.S.A. and adopt foul means for that so they break the ethical circles without any hesitation. Greed often inspires them to take wicked steps. How could Arthur Miller tolerate even Lucifer who 
wanted to be equal to God and hence he exposed his evils designs in A Creation Of The World And Other Business. In After The Fall the artist describes the difference between innocent Adam and Eve and modern American men and women who had become mad for material gains. Now they had stopped following traditions and social norms and accepted divorce easily. Quintin wants to marry third time so that he may begin a new life with vigour and zeal. He has lost interest in his previous two wives and accepts Holga's advice for a new life. Old circles of marriage have no meaning for him as he wants to enter the third circle of life with Holga. Yet he finds it difficult to do so as it is not easy to forget the past. As a matter of fact Miller also took divorce from film actress Marylin Munroe and then planned to marry third time.

So, Miller basically believed in positive approach to life and condemned the people who pretended to be religious, pure and holy. With his tragedies he asserted the importance of self-realization and self-illumination as life can't be lived with narrow vision. The men of limited vision fail to analyze all the aspects of divine life and don't understand the working of eternal Nature. After all God reveals Himself through transcendental Nature everyday and every year. Everyone must possess comprehensive vision to perform blissful service to family and society. He has to analyze the meaning of ultimate creative ideals as life can't be lived only for physical and intellectual satisfaction. Nobody can understand the working of divine forces if he is busy in seeking sensual pleasures. Consciousness has got to be awakened to get rid of ignorance, vanities and frivolities. Hence service of mankind as a whole has got to be rendered by all human beings and only then we can reach El Dorado. They have to work and die for impersonal evolution and not remain limited to personal gains. 


\section{Works Cited}

Miller, Arthur. The Crucible in Collected Plays. New Delhi: Allied Publishers (P) Ltd. 1973.

Adler, Thomas P. in Christopher Bigsby, The Cambridge Companion To Arthur Miller. Cambridge: Cambridge University Press, 1997.

Kumar, Shiv (ed.) Essays Ralph W. Emerson. New Delhi: Eurasia Pub. House (P.) Ltd. 1965 . 